ISSN (print): 1698-6180. ISSN (online): 1886-7995

www.ucm.es/info/estratig/journal.htm

Journal of Iberian Geology 37 (2) 2011: 153-160

doi: 10.5209/rev_JIGE.2011.v37.n2.4

\title{
Discussion about the stratigraphic range of Pseudofurnishius murcianus van den Boogaard (Conodonta) in the Iberian Peninsula, from the Calasparra section (Murcia, Spain)
}

\author{
Discusión sobre la distribución estratigráfica de Pseudofurnishius murcianus \\ van den Boogaard (Conodonta) en la Península Ibérica, a partir de la sección \\ de Calasparra (Murcia, España)
}

\author{
P. Plasencia ${ }^{1, *}$, A. Márquez-Aliaga ${ }^{2}$ \\ ${ }^{1}$ State Key Laboratory of Palaeobiology and Stratigraphy, Nanjing Institute of Geology and Palaeontology, \\ 39 East Beijing Road, 210008 Nanjing, China. \\ ${ }^{2}$ Departamento de Geología e ICBiBE, Universidad de Valencia, Dr. Moliner, 50, Burjassot, 46100 Valencia, Spain \\ *corresponding author: pablo.plasencia@uv.es
}

Received: 13/06/11 / Accepted: 21/10/11

\begin{abstract}
The biostratigraphy of Calasparra Section is well-estabished with an ammonoid biozonation and ranges from Lower to Upper Ladinian. The continuous presence of Pseudofurnishius murcianus van den Boogaard, a characteristic conodont species of the Sephardic realm, along the section makes it one of the most important sections in the Iberian Peninsula for the study of the species. The first apparition of $P$. murcianus in the section corresponds with the first of Eoprotrachyceras curionii taxon, which is the principal marker for the base of the Ladinian stage in the GSSP of the Anisian-Ladinian boundary, and the age of the youngest conodonts, based on ammonoids (Epigonus Zone) is Lower Ladinian (upper Fassanian). This is similar to the range of P. murcianus in the Saharonim Formation in Israel, where its earliest appearance is also Early Fassanian (Curionii zone) age.
\end{abstract}

Keywords: Conodonts, bivalves, Betic Cordillera, Middle Triassic, Spain

Resumen

La bioestratigrafía de la Sección de Calasparra está bien establecida mediante biozonación de ammonoideos, con una edad que va desde el Ladiniense inferior hasta el Longobardiense. La presencia continua de Pseudofurnishius murcianus van den Boogaard, una especie de conodontos característica del Dominio Sephardí, a lo largo de la sección la hace una de las más importantes de la Península Ibérica para el estudio de la especie. La primera aparición de P. murcianus en la sección se corresponde con el taxón Eoprotachyceras curionii, que es el principal marcador para la base del piso Ladiniense en el GSSP del límite Anisiense-Ladiniense, mientras que la edad de los conodontos más recientes, basada en ammonites (Epigonus Zone) es Ladiniense Inferior (Fassaniense superior) Este rango es similar al de P. murcianus en la Formación Saharonim en Israel, de edad Fassaniense inferior (Zona Curionii).

Palabras clave: Conodontos, bivalvos, Cordillera Bética, Triásico Medio, España 


\section{Introduction}

The Betic Cordillera is a mountain system in southern Spain that extends in SW-NE direction from the city of Cadiz on the Atlantic Ocean to the Balearic Islands in the Mediterranean. The Cordillera is part of the Gibraltar Arc that represents the westernmost part of the Alpine system, generated by the convergence of the African and Iberian plates in Tertiary times (Vera, 2001; López-Gómez, 2002; Martín-Algarra and Vera, 2004; Pérez-Lopez and PérezVarela, 2007).

Extending S-SE of the Iberian Massif and Guadalquivir Valley, the External Zone of the Betic Cordillera is divided in the large Prebetic and Subbetic tectono-stratigraphic domains (Fig. 1), that comprise thrust-sheets of Triassic to Miocene mainly marine successions (Pérez-Lopez and Pérez-Varela, 2007). The Prebetic is the nearest to the Iberian Masif while the Subbetic is the more distant. The Internal Zone in the southernmost part of the Betic Cordillera is strongly deformed and frequently showing metamorphism.

Our study area, southeast of Calasparra (NE of the province of Murcia) straddles the limit between the Prebetic and Subbetic domains.

The section presents traditional "Germanic-type" units (Pérez-Valera and Pérez-López, 2003). The lower one is of Budsandstein facies, formed by detritic red sandstones and clays. Above it, Muschelkalk deposits consist of carbonate successions of dolomites, limestones and marly limestones, increasingly dominated by marls towards the upper part. This unit was defined as Cehegín Formation (Pérez-Valera and Pérez-López, 2008) and can be correlated with the Majanillos Formation (Pérez-López, 1991) that was defined in the central part of the Betic Cordillera. Finally, a detrital-evaporitic unit with shale, sandstone, gypsum, and occasional basic subvolcanic rocks represents a characteristic Keuper facies that belong to the Jaén Keuper Group (Pérez-López 1991). Our study encompasses the Muschelkalk deposits of the Cehegín Formation.

\section{Biostratigraphy}

The section, located SE of the locality of Calasparra (Murcia) and S of the Sierra de Molino (MAGNA sheet $\mathrm{N}^{\mathrm{o}} 890$ “Calasparra”, coordinates $38^{\circ} 12^{\prime} 30^{\prime} \mathrm{N}^{\circ} 38^{\circ} 10$ W). The column, $90 \mathrm{~m}$ thick, comprises five units based on the ammomoid biozonation of Pérez-Valera et al. (2005), Pérez-Valera and Pérez-López (2008) and PérezValera et al. (2011) (Fig. 2).

Unit 1: $8 \mathrm{~m}$ thick, and above the Buntsandstein facies; is mainly composed of thick laminated dolomite packs, with algal structures and evaporate moulds in different degrees of bioturbation. On top, a fossiliferous level of black nodular limestone yielding numerous fragments of bivalves and small gastropods, foraminifers like Lamelliconus? sp., crinoids, fish micro-remains and polen, is covered by a hardground.

Unit 2: $25 \mathrm{~m}$ thick, in the base presents a ferruginous bioclastic nodular limestone with intensive bioturbation
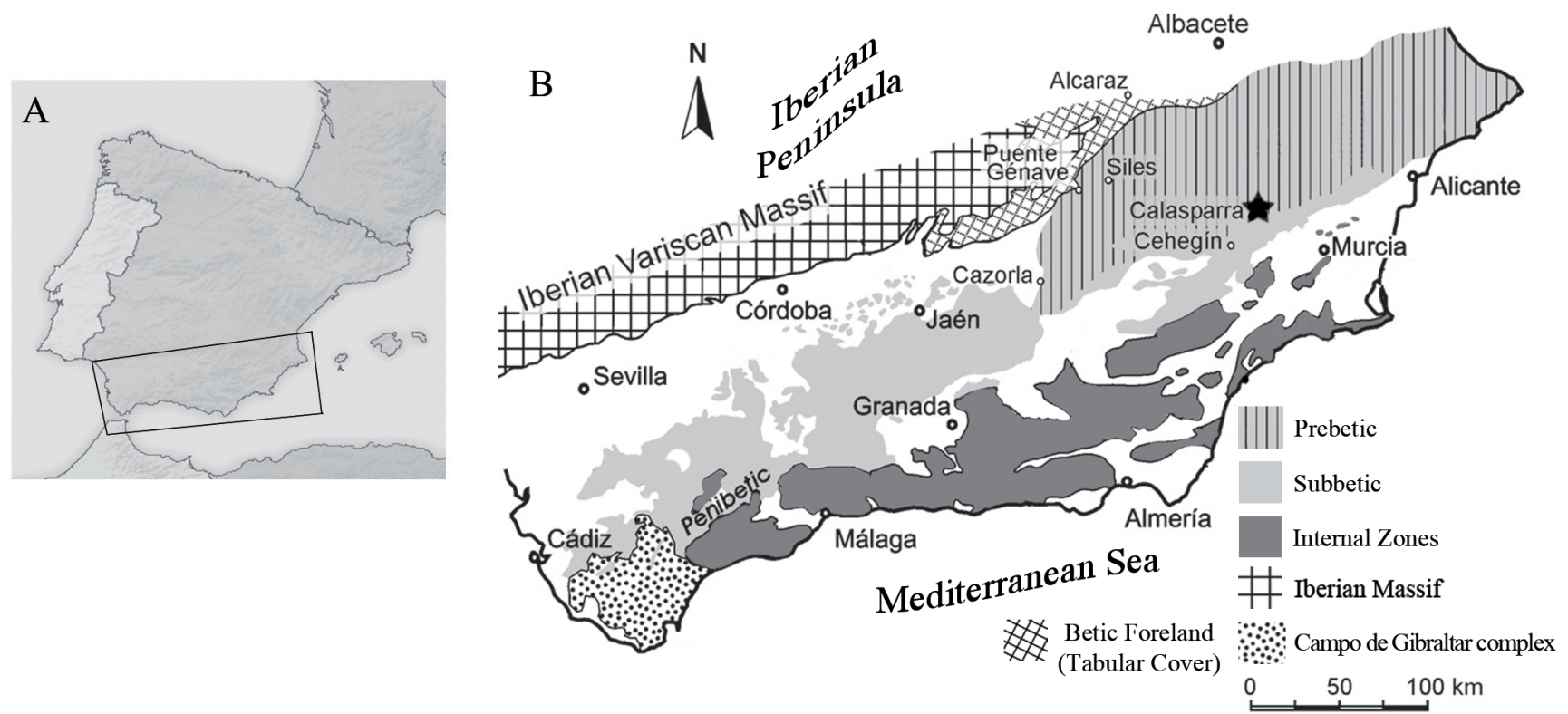

Fig. 1 - Main tectonic units in the Betic Cordillera; star marks location of the section at Calasparra (Modified from Pérez-López and Pérez-Valera (2007).

Fig. 1 - Principales unidades tectónicas de la Cordillera Bética; la estrella señala la localización de la sección en Calasparra (Modificado de Pérez-López y Pérez-Valera (2007) 
S

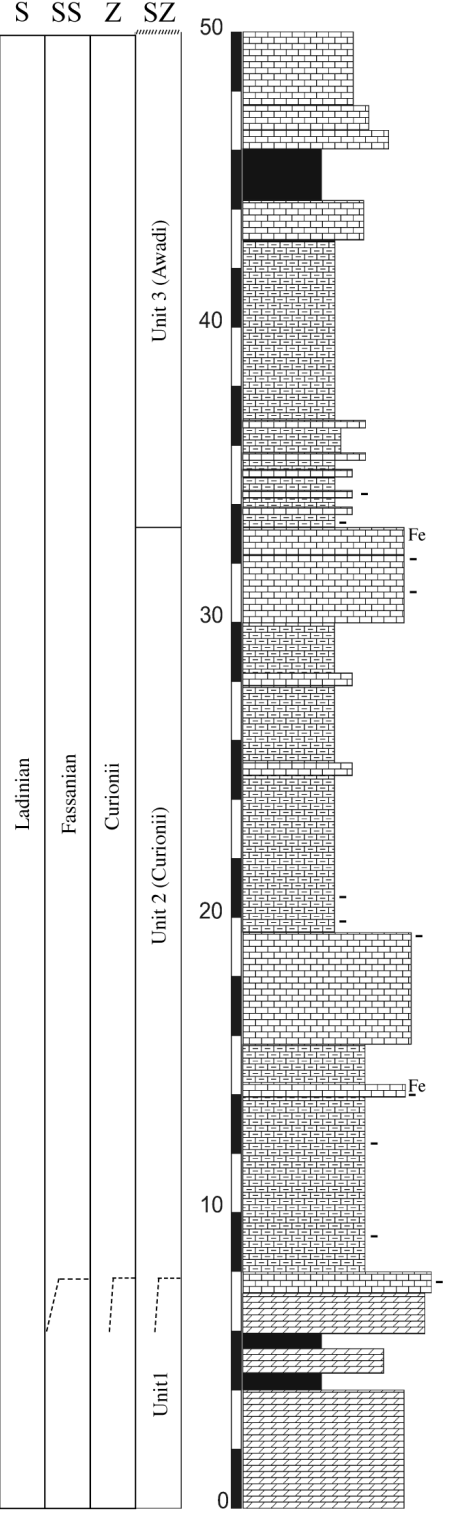

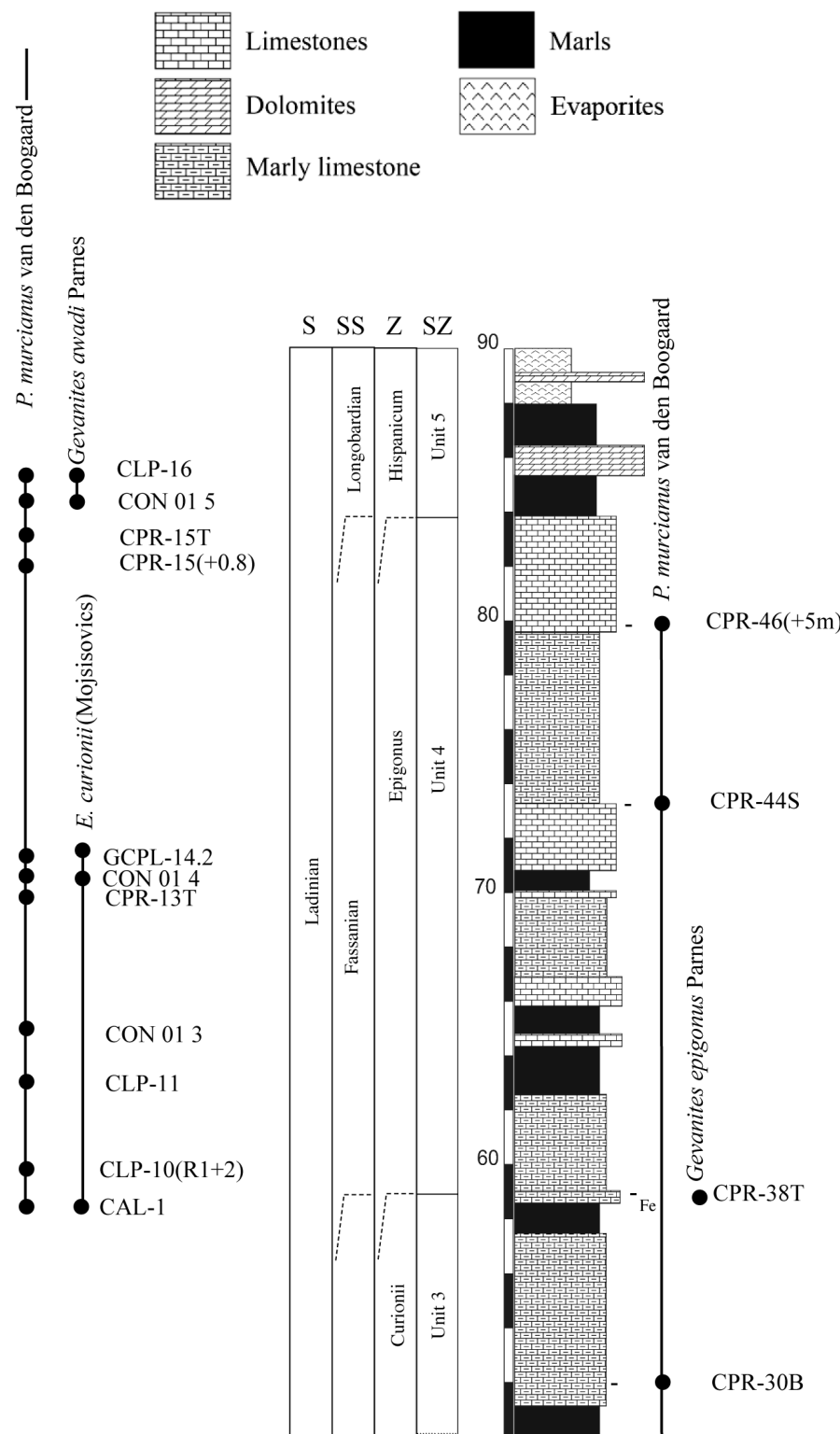

Umbostrea sp. and Unicardium sp. and foraminifers like L. cf. multispirus (Overhauser), L. aff. procerus (Liebus) and Pilamminella generica Salaj, T. eomesozoicus (Oberhauser) and Aulotortus praegaschei (Koehn-Zaninetti) (Márquez-Aliaga et al., 1999; Márquez-Aliaga and Márquez, 2000). The unit corresponds to the Curionii subzone, characterized by Eotrachyceras curionii (Mojsisovics) that marks the lower part of the Curionii Zone, the base of the Fassanian (Lower Ladinian). Other ammonoids found in the unit are Israelites ramonensis Parnes and Negebites zaki Parnes (Pérez-Valera et al. 2011).

Unit 3: $25 \mathrm{~m}$ thick, is formed by lightly bioturbed layers of grey marls alternating with marly limestone (mudstone to wackestone), with few bioclasts and variable bioturbation. Higher up in the unit, marly limestone and marls

with lutite and thin-bedded bioclastic limestone levels
15T, CON 01 5, CLP-16 at the top), fish micro-remains, briozoans, echinoderms, bivalves like Costatoria sp., 
alternate. At top, the unit ends with a hardground of ferruginous limestone, with many bioclasts, especially bivalves. Fossil record is more abundant in the lower part of the unit, which starts with the appearance of Gevanites awadi Parnes at its base. Among ammonoids further occur Gevanites virgiliae Goy and Gevanites altecarinatus Parnes (Pérez-Valera, 2005; Pérez-Valera et al., 2011). The fossil record include also bivalves as Plagiostoma striata (Schlotheim), Chlamys schroeteri (Giebel), Chlamys sp., Gervilleia joleaudi Schmidt, Leptochondria alberti (Goldfuss), Modiolus myoconchaeformis (Philippi), Pseudocorbula gregaria (Münster), Pleuromya elongata (Schlotheim), Costatoria kiliani (Schmidt), Neoschyzodus laevigatus (Goldfuss), Bakevellia costata (Schlotheim),"Enatiostreon"cf. flabellum Schmidt and Unionites sp., foraminifers as Lamelliconus cf. procerus (Liebus), Nodosaria ordinata Trifonova, the annelid Spirorbis phlyctaena Bronnimann and Zaninetti and gastropods. (Márquez-Aliaga et al., 1999; Márquez-Aliaga and Márquez, 2000) Microfossils include conodonts ( $P$. murcianus, in samples CON 01 5, CLP-16 at base and CPR-30B at top) and fish micro-remains. Gevanites awa$d i$ allows the attribution of the unit to the Awadi- subzone of the Fassanian Curionii-Zone (lower Ladinian).

Unit 4: $24 \mathrm{~m}$ thick, consists of alternating marls and marly limestones. Further up, most of the unit consists of alternations of platy bioclastic limestone, marls and lutite levels. The fossil record starts at its base with the first apparition of Gevanites epigonus Parnes. This rather scarce unit yields bivalves ( . gregaria, Bakevellia sp.) and gastropods; microfossils include $P$. murcianus (samples CPR-44S and CPR-46(+5m) and fish micro- remains. Gevanites epigonus Parnes attributes this unit to the Epigonus zone, equivalent to the "Eoprotrachyceras" gredleri zone in Balini et al. (2010), of upper part of the Fassanian, (Lower Ladinian).

Unit 5: $6 \mathrm{~m}$ thick, is formed by brown dolomites, evaportites, few green lutites and finally a grey and white chalk level that represent the transition to a regressive episode of Keuper facies. It is possible that this unit corresponds to the Hispanicum zone, characterized by Protrachyceras hispanicum, and of Longobardian (upper Ladinan) age. Perez-Valera et al. (2011) cited a record of $P$. hispanicum in the equivalent levels of a close outcrop.

In agreement with the acceptance by the ISTS of the proposition of the Ladinian GPSS at the base of Curionii Zone (as proposed by Bracks et al. 2003), the first occurrence of E. curionii var. ramonensis in the section of Calasparra would correspond with the base of the lower Fassanian (Lower Ladinian) Curionii Zone. The Awadi -Subzone would correspond to the middle Fassanian, the Epigonus Zone to the upper Fassanian and the top of the section could be Hispanicum zone (lower Longobardian).

\section{The conodont fauna at Calasparra}

Conodonts from Calasparra belong to Pseudofurnishius murcianus van den Boogaard, the most common Middle Triassic species in the Iberian Peninsula. The denticulated platform that appears on, at least, the inner side of the $\mathrm{P}_{1}$ element, makes $P$. murcianus a very characteristic species, easily distinguishable from other coetaneous conodont species. A very wide morphological variability of this structure develops during ontogeny, especially

Fig. 3 - Conodonts of the section of Calasparra. Pseudofurnishius murcianus van den Boogaard. Specimens deposited in the Museum of Geology of the University of Valencia. Upper, lower, inner and outer views. All scales $50 \mu \mathrm{m}$.

Right $\mathrm{P}_{1}$ element. CLP-6. MGUV-10251. Unit 2, lower Ladinian (Subzone Curionii, early Fassanian).

Left $\mathrm{P}_{1}$ element. CLP-6. MGUV-10255. Unit 2, lower Ladinian (Subzone Curionii, early Fassanian).

Right $\mathrm{P}_{1}$ element. CLP-8. MGUV-10258. Unit 2, lower Ladinian (Subzone Curionii, early Fassanian).

Right $P_{1}$ element. CON 01 2. MGUV-10307. Unit 2, lower Ladinian (Subzone Curionii, early Fassanian).

Right $\mathrm{P}_{1}$ element. CLP-11. MGUV-10325. Unit 2, lower Ladinian (Subzone Curionii, early Fassanian).

Left $P_{1}$ element. GCLP-14.2. MGUV-10334. Unit 2, lower Ladinian (Subzone Curionii, early Fassanian).

Right $P_{1}$ element. CON 01 5. MGUV-10336. Unit 3, lower Ladinian (Subzone Awadi, early-late Fassanian).

Right $P_{1}$ element. CPR-44. MGUV-10347. Unit 4, lower Ladinian (Zone Epigonus, late Fassanian).

Right $\mathrm{P}_{1}$ element. CPR-46. MGUV-10358. Unit 4, lower Ladinian (Zone Epigonus, late Fassanian).

Fig. 3 - Conodontos de la sección de Calaparra. Pseudofurnishius murcianus van den Boogaard. Especímenes depositados en el Museo de Geología de la Universidad de Valencia Vistas superior, inferior, interna y externa. Todas las escalas $50 \mu \mathrm{m}$.

Elemento $\mathrm{P}_{1}$ derecho. CLP-6. MGUV-10251. Unidad 2, Ladiniense inferior (Subzona Curionii, Fassaniense inferior).

Elemento P izquierdo. CLP-6. MGUV-10255. Unidad 2, Ladiniense inferior (Subzona Curionii, Fassaniense inferior).

Elemento $\mathrm{P}_{1}$ derecho. CLP-8. MGUV-10258. Unidad 2, Ladiniense inferior (Subzona Curionii, Fassaniense inferior).

Elemento $\mathrm{P}_{1}$ derecho. CON 01 2. MGUV-10307. Unidad 2, Ladiniense inferior (Subzona Curionii, Fassaniense inferior).

Elemento $\mathrm{P}_{1}$ derecho. CLP-11. MGUV-10325. Unidad 2, Ladiniense inferior (Subzona Curionii, Fassaniense inferior).

Elemento P izquierdo. GCLP-14.2. MGUV-10334. Unidad 2, Ladiniense inferior (Subzona Curionii, Fassaniense inferior).

Elemento $\mathrm{P}_{1}$ derecho. CON 01 5. MGUV-10336. Unidad 3, Ladiniense inferior (Subzona Awadi, Fassaniense superior-inferior).

Elemento $\mathrm{P}_{1}$ derecho. CPR-44. MGUV-10347. Unidad 4, Ladiniense inferior (Subzona Curionii, Fassaniense superior).

Elemento $\mathrm{P}_{1}$ derecho. CPR-44. MGUV-10358. Unidad 4, Ladiniense inferior (Subzona Curionii, Fassaniense superior). 


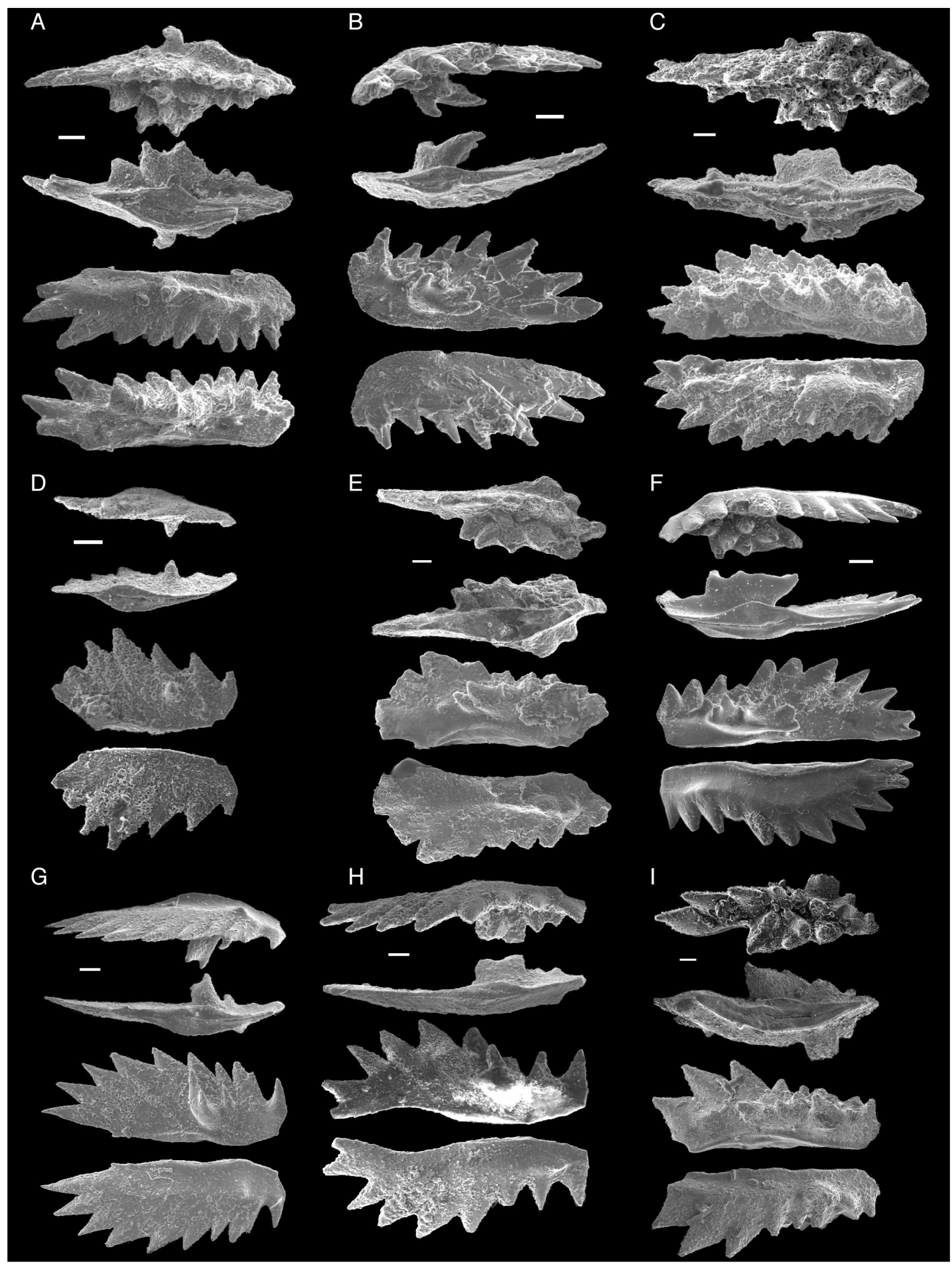




\begin{tabular}{ccccc} 
& & $\begin{array}{c}\text { P. } \\
\text { murcianus }\end{array}$ & $\begin{array}{c}\text { M } \\
\text { elements }\end{array}$ & $\begin{array}{c}\text { S } \\
\text { elements }\end{array}$ \\
\hline Unit 4 & CPR-46(+5m) & 1 & & \\
& CPR-44S & 9 & 2 & 2 \\
\hline Unit 3 & CPR-30B & & & \\
& CLP-16 & 1 & & \\
& CON 01 5 & 4 & & 1 \\
\hline Unit 2 & CPR-15T & & & \\
& CPR-15(+0.8) & & \\
& GCLP-14.2 & 1 & & \\
& CON 01 4 & 4 & & \\
& CPR-13T & 2 & 2 & \\
CON 01 3 & 3 & & 1 \\
CLP-11 & 3 & & \\
CLP-10(R1+2) & 1 & & \\
CPR-10.4 & 2 & 5 & \\
CON 01 2 & 45 & 11 & \\
CLP-8 & 18 & 2 & \\
\hline & CLP-6 & 6 &
\end{tabular}

Table 1 - Samples with conodont fossil record in the section of Calasparra.

Tabla 1 - Muestras con registro fósil de conodontos en la sección de Calasparra.

in the more developed stages of the species (Bandel and Waksmundzki, 1985; Plasencia, 2009; Plasencia et al., 2010), and not uncommon is the presence of one or more denticles on the outer side that in some specimens forms a platform that can overgrow the inner one, generating biplatform specimens.

The preservation of the material is in general good, with the most common alterations being broken elements, and, in some specimens, a heavy surface alteration. The collected specimens represent different ontogenetic stages of the species, from the less developed, with one denticle on the inner platform (Fig. C, D and G) to well developed ones with denticles on an outer platform (Fig. 3, A, C, E and I) or naked (Fig. 3, B, F and H). A synthesis of the conodont bearing samples can be found in Table 1 .

\section{Discussing the age of Pseudofurnishius murcianus}

Pseudofurnishius murcianus is an important Ladinian biostratigraphic marker of the Sephardic province as it is often the only species found in many localities. Its stratigraphic range has been the object of discussion for a long time. Since Simon (1966) ascribed a Middle to Upper Triassic age to the rocks from which van den Boogaard (1966) described the species, several opinions have been published. One advocates an Early Ladinian origin while others prefer an Upper Ladinian (Longobardian) age.

In the first group, Hirsch (1972) proposed a Lower to Upper Ladinian age based on the ammonoids in the Saharonim Formation (Israel) found together with P. murcianus, and suggested a possible Upper Anisian origin. In
Hirsch and Gerry (1974), a Lower Ladinian to Early Upper Ladinian age was suggested for the Pseudofurnishius assemblage zone, and an Upper Ladinian age for the Pseudofurnishius murcianus - Epigondolella mungoensis zone. Recently, Plasencia et al. (2007) pointed out an Early Fassanian age for P. murcianus.

The second group, that includes, among others, Nicora (1981), Gullo and Kozur (1991) and Kozur (1993), pointed to a Late Ladinian (upper Longobardian) origin of $P$. murcianus and a range up into the Early Carnian. The second authors proposed a phylomorphogenetic lineage that included Pseudofurnishius priscus, $P$. huddlei and several subspecies of $P$. murcianus ( $P$. murcianus praecursor, $P$. murcianus murcianus and $P$. murcianus n. subsp. B), based mainly on the progressive reduction and final disappearance of the outer platform and stage of development of the inner platform. Using this scheme, they proposed a lower middle Longobardian age for $P$. huddlei and a middle Longobardian to Cordevolian age for $P$. murcianus, while successive subspecies of $P$. murcianus, overlapping each other, comprised associations, successively dominated by $P$. murcianus praecursor (early - middle Longobardian), P. murcianus murcianus (upper Longobardian) and P. murcianus n. sp. B (Cordevolian).

It must be emphasized here that while an Early Ladinian to Upper Ladinian range for P. murcianus applies well within the Sephardic realm, the shift of slightly hypersaline environments to South Alpine Tethys periphery towards the end of the Ladinian, which persevered during the Early Carnian, brought typical Sephardic biota outside the Sephardic Realm.

As Calasparra has a well-established biostratigraphy with materials that range from Fassanian (Curionii and Awadi Subzones, Epigonus Zone) to lower Longobardian (Hispanicum Zone), the presence of $P$. murcianus in different samples along the Fassanian materials makes the section one of the most complete Middle Triassic sections, not only in the Betic Cordillera, but also in the whole Iberian Peninsula, to study the early evolution of the species.

The conodonts found in Calasparra are of special importance, especially the specimens from unit 1 and the lower part of the Unit 2 (Fig. 3, A-C). This is the first time that such an early age for Pseudofurnishius murcianus has been evidenced in the Iberian Peninsula. Moreover, they are of similar age than P. murcianus in the Saharonim Formation at Ramon in Israel, found in the same interval as a rich cephalopod assemblage comprising among others E. curionii ramonensis, of early Ladinian (lowermost Fassanian) age (Huddle, 1970; Hirsch and Gerry, 1974; Benjamini et al., 2005). Thus, the stratigraphical range 
of $P$. murcianus should be lowered in the Iberian Peninsula thanks to the findings in Calasparra close and below Israelites ramonensis Parnes fossils (Pérez-Valera et al., 2011).

For the upper limit of $P$. murcianus, a Lower Carnian (Lower Cordevolian) age in the northern Apuseni Mountains was proposed by Kozur (1980), where the species appears together with Sephardiella diebeli, S. mostleri, Metapolygnathus polygnathiformis and M. tadpole. Since then, several authors (Nicora, 1981, Gullo and Kozur, 1991, Kozur, 1993 or Rigo et al., 2006) found P. murcianus in Upper Ladinian or Early Carnian levels. In Calasparra, the age of the youngest conodonts in the section (Unit 4, Fig. 3, 8-9), based on ammonoids (G. epigonus) is Lower Ladinian (upper Fassanian).

\section{Conclusions}

The Calasparra section has a well-established biostratigraphy thanks to an ammonoid biozonation that ranges from Upper Anisian (Illyrian) to Upper Ladinian (Longobardian) The continuous occurrence of $P$. murcianus within the Fassanian materials of the section makes it one of the most important localities in the Iberian Peninsula for the study of the evolution of the species.

It is of special significance that, mainly as a consequence of the establishment of the Ladinian GSSP at the base of the Curionii Zone in the Southern Alps, the first occurrence of $P$. murcianus, in the two lower units of the Calasparra section, is Fassanian (Lower Ladinian). That confirms the age given by Hirsch (1972), Hirsch and Gerry (1974) and Plasencia (2007) for the species.

\section{Acknowledgements}

We want to thank to Drs. Francis Hirsch (Naruto University of Education, Japan) Alberto Pérez-López (University of Granada, Spain) and Juan Alberto Pérez-Valera (Complutense University of Madrid, Spain) for his comments, which helped us to improve the results.

This work has been supported by the Chinese Academy of Sciences (Young International Scientist Grant "2010Y2ZA02") and by the "Agencia Española de Cooperación Internacional para el Desarrollo" of the "Ministerio de Asuntos Exteriores y Cooperación (MAEC-AECID)".

\section{References}

Balini, M., Lucas, S.G., Jenks, J.F., Spielmann, J.A. (2011) The Triassic Timescale. Geological Society, London, Special Publications, 334, 221-262. doi: 10.1144/SP334.10.
Bandel, K. Waksmundzki, B. (1985): Triassic conodonts from Jordan. Acta Palaeontologica Polonica, 35: 3-4, 289-304.

Benjamini, C., Hirsch, F., Eshet, Y. (2005): The Triassic of Israel. In: J.K. Hall, V.A. Krasheninnikov, F. Hirsch, C. Benjamini, A. Flexer (eds.) Geological Framework of the Levant Volume II: The Levantine Basin and Israel. Historical Productions Hall, II: 331-360.

Brack, P., Rieber, H., Nicora, A. (2003): The Global Stratigraphic Section and Point (GSSP) of the base of the Ladinian Stage (Middle Triassic). A proposal for the GSSP at the base of the Curionii Zone in the Bagolino section (Southern Alps, Northern Italy). Albertiana, 28: 13-25.

Gullo, M., Kozur, H. (1991): Taxonomy, stratigraphic and paleogeographic significance of the Late Ladinian - Early Carnian conodont genus Pseudofurnishius. Palaeontographica Abteilung A: Palaozoologie-Stratigraphie, 218: 69-86.

Hirsch, F. (1972): Middle Triassic conodonts from Israel, southern France and Spain. Mitteilungen der Gesellschaft der Geologie- und Bergbaustudenten, 21: 811-828.

Hirsch, F., Gerry, E. (1974): Conodont and Ostracode Biostratigraphy of the Triassic in Israel. Schriftenreihe der Erdwissenschaftlichen Kommissionen, 2: 101-114.

Huddle, J.W. (1970): Triassic conodonts from Israel. U.S. Geological Survey Research, 700B: 124-130.

Jerez, L., García Monzón, G., Jerez, L., Martínez, C., Moreno, E., Perconing, E., Granados, L. (1974): Hoja geológica num. 890 (Calasparra). Mapa Geológico de España E. 1:50.000. Segunda serie, I.G.M.E., Madrid.

Kozur, H. (1980): Revision der conodontenzonierung der Mittel- und Overtrias des tethyalen Faunenreischs. Geologisch Palaeontologische Mitteilungen Innsbruck, 10, 3/4: 79-172.

Kozur, H. (1993): First evidence of Pseudofurnishius (Conodonta) in the Triassic of Hungary. Jahrbuch der Geologischen Bundesanstalt, 136, 4: 783-193.

López-Gómez, J., Arche, A., Pérez-López, A. (2002): Permian and Triassic. In: T. Gibbons and T. Moreno (eds.), The Geology of Spain. The Geological Society, London: 187-212.

Nicora, A. (1981): Pseudofurnishius murcianus, van den Boogaard, in Upper Triassic in southern Alps and Turkey. Rivista Italiana di Paleontologia e Stratigrafia, 86, 4: 769778.

Márquez-Aliaga, A., Márquez, L., Ros, S., Goy, A. 1999. Aspectos tafonómicos de bivalvos del Triásico Medio de Calasparra (Murcia). Colección Temas Geológico-Mineros. I.T.G.E., 26 (1): 260-261.

Márquez-Aliaga, A., Márquez, L. 2000. Fosildiagénesis de bivalvos del Triásico Medio del Prebético (Murcia, España): una aproximación. Boletín Geológico y Minero, 111 (5): 3346.

Martín-Algarra, A., Vera J.A. (2004): La Cordillera Bética y las Baleares en el contexto del Mediterráneo Occidental. In: Vera, J.A. (Ed.). Geología de España. SGE-IGME, Madrid, 352-354.

Pérez-López, A. (1991): El Trías de facies germánica del sector central de la Cordillera Bética. PhD Thesis, University of Granada, $400 \mathrm{pp}$.

Pérez-López, A., Pérez-Valera, F. (2007) : Palaeogeography, 
facies and nomenclature of the Triassic units in the different domains of the Betic Cordillera (S Spain). Palaeogeography, Palaeoclimatology, Palaeoecology, 254: 606-626. doi:10.1016/j.palaeo.2007.07.012.

Pérez-Valera, J.A, Goy, A., Pérez-Valera F. and Pérez-López, A. (2011): Ammonoid biostratigraphy of Muschelkalk carbonates (Ladinian) of the South-Iberian Triassic (Betic External Zones, S Spain). Sixième réunion du Groupe Marocain du Permien et du Trias, Tétouan, 20-21 Mai, Livret des résumés, 20-21.

Pérez-Valera, F., Pérez-López, A. (2003) : Estratigrafía y tectónica del Triásico sudibérico al sureste de Calasparra (Murcia). Revista de la Sociedad Geológica de España, 16: 1-2, 32-50.

Pérez-Valera, F. and Pérez-López, A. (2008): Stratigraphy and sedimentology of Muschelkalk carbonates of the Southern Iberian Continental Palaeomargin (Siles and Cehegín Formations, Southern Spain). Facies, 54, 61-87. doi:10.1007/ s10347-007-0125-1.

Pérez-Varela, J.A., Pérez-Varela, F., Goy, A. (2005) : Bioestratigrafía del Ladiniense Inferior en la región de Calasparra (Murcia, España). Geotemas, 8: 211-215.

Plasencia, P. (2009): Bioestratigrafía y paleobiología de conodontos del Triásico Medio del Sector Oriental de la Península Ibérica. Servei de Publicacions de la Universitat de Valencia, 408 pp.
Plasencia, P., Hirsch, F., Márquez-Aliaga, A. (2007): Sephardiellinae, a new Middle Triassic conodont subfamily. Journal of Iberian Geology, 33, 2: 163-172. doi:10.1016/j.geobios.2010.02.003

Plasencia, P., Hirsch, F, Márquez-Aliaga, A. (2010): On the ontogeny and orientation of the Triassic Conodont P1-element in Pseudofurnishius murcianus Van den Boogaard, 1966. Geobios, 43: 5, 547-553.

Rigo, M., Preto, N. Roghi, G. Tateo, F., Mietto, P. (2006): A rise in the Carbonate Compensation Depth of western Tethys in the Carnian (Late Triassic): Deep-water evidence for the Carnian Pluvial Event. Palaeogeography, Palaeoclimatology, Palaeoecology, 246: 188-205. doi:10.1016/j.palaeo.2006.09.013.

Simon, O.J. (1966): The age of the conodont-bearing carbonate rocks from the Sierras of Carrascoy, de Almagro and Alhamilla and from the Zarcilla de Ramos region (SE Spain). Koninklijke Nederlandse Akademie Van Wetenschappen, sér. B, 69: 5, 9-19.

van den Boogaard, M. (1966): Post-Carboniferous conodonts from south-eastern Spain. Koninklijke Nederlandse Akademie van Wetenschappen, sér. B, 69: 5, 1-8.

Vera, J.A. (2001): Evolution of the South Iberian Continental Margin. In: Ziegler PA, Cavazza W, Robertson AHF, Crasquin-Soleau S (eds) Peri-Tethys Memoir 6: Peri-Tethys Rift/ Wrench Basins and Passive Margins. Mém Mus Natn Hist Nat 186: 109-14. 